\title{
The oxidation of HSP70 is associated with functional impairment and lack of stimulatory capacity
}

\author{
Marcelo Sartori Grunwald • André Simões Pires • Alfeu Zanotto-Filho • \\ Juciano Gasparotto • Daniel Pens Gelain • Diogo Ribeiro Demartini • \\ Cinthia Maria Schöler • Paulo Ivo Homem de Bittencourt Jr • \\ José Cláudio Fonseca Moreira
}

Received: 4 October 2013 /Revised: 25 April 2014 / Accepted: 27 April 2014 / Published online: 10 May 2014

(C) Cell Stress Society International 2014

\begin{abstract}
Expression of intracellular HSP70 is associated with cytoprotective effects against a wide range of stressful stimuli, such as inflammation, oxidative stress, hypoxia, endotoxins, infections, and fever. This cytoprotective effect is mainly attributed to their ability to stabilize protein structures through chaperone-like reversible interactions. HSP70 was recently detected in the extracellular medium, and its presence in serum is commonly associated with pathological situations, where it exerts modulatory effects on cells of the immune system. Previously, we have described the relationship between serum HSP70 levels, oxidant status, and clinical outcome of septic patients; the group of patients with higher prooxidant status and higher serum HSP70 had also higher mortality. To investigate the possible association between oxidized HSP70 and cytoprotection or cell death, we incubated RAW 264.7 macrophages with oxidized HSP70 and evaluated nitrite production, cell proliferation, cell viability, TNF- $\alpha$ release, and phagocytic activity. We also evaluated structural modifications caused by oxidation in purified HSP70. Oxidation of HSP70 altered its protein structure;
\end{abstract}

\footnotetext{
M. S. Grunwald $(\bowtie) \cdot$ A. S. Pires $\cdot$ A. Zanotto-Filho

J. Gasparotto · D. P. Gelain · J. C. F. Moreira

Departamento de Bioquímica, Instituto de Ciências Básicas da Saúde, Universidade Federal do Rio Grande do Sul, Rua Ramiro Barcelos, 2600, Porto Alegre, Rio Grande do Sul CEP 90035-003, Brazil

e-mail: marcelo.sartori@yahoo.com.br

D. R. Demartini

Centro de Biotecnologia, Universidade Federal do Rio Grande do

Sul, Porto Alegre, Rio Grande do Sul, Brazil

C. M. Schöler • P. I. H. de Bittencourt Jr

Departamento de Fisiologia, Instituto de Ciências Básicas da Saúde, Universidade Federal do Rio Grande do Sul, Porto Alegre, Rio Grande do Sul, Brazil
}

besides, the modulatory effect of oxidized HSP70 on RAW264.7 cells was different from that of native HSP70. Macrophages treated with oxidized HSP70 presented lower proliferation and viability, lower phagocytic activity, and lower TNF- $\alpha$ release. These results indicate that oxidation of extracellular HSP70 modified its signaling properties, causing alterations on its modulatory effects on macrophage function and viability.

Keywords HSP70 $\cdot$ Inflammation $\cdot$ Oxidative modifications $\cdot$ Macrophage activation

\section{Introduction}

Heat shock proteins (HSPs) were first described in 1962 when Ferrucio Ritossa accidentally exposed salivary gland cells to a heat shock (Ritossa 1962). They function as ATP-dependent molecular chaperones, transporting intracellular proteins in cells under stress and assisting the correct folding and stabilization of damaged proteins. Since then, these proteins have been associated with many other stressful stimuli, including inflammation and oxidative stress (Jaattela 1999; Lindquist and Craig 1988), gaining a new cytoprotective function. Upregulation of intracellular HSP70 results in protective effects against hypoxia, excess oxygen radicals, endotoxins, and infections (Wong et al. 1997; Wong et al. 1998; Villar et al. 1994; Ryan et al. 1992). This cytoprotective effect is attributed to their ability to stabilize protein structures through chaperone-like reversible interactions (Ribeiro et al. 1994). Members of the heat shock superfamily have a highly conserved structure, being present from bacteria to mammals. HSP70 has an amino acid sequence constituted approximately by 700 residues that form a $70-\mathrm{kDa}$ protein with two different domains: the nucleotide binding domain (NBD) and the 
substrate binding domain (SBD). HSPs are distributed in diverse cell compartments, including the cytosol, nucleus, and membrane organelles. HSP70 has been observed to be translocated to the plasma membrane and released to extracellular environments, where they exert modulatory effects in cells of the immune system (Asea 2007; Asea et al. 2000, 2002); in addition, serum HSP70 is associated with stress conditions such as inflammation, bacterial or viral infections, and oncological diseases (Pittet et al. 2002; Pockley et al. 2003; Barreto et al. 2003).

In humans, extracellular HSP70 (eHSP70) is known to be released into the systemic circulation by the brain and hepatosplanchnic tissue (Lancaster et al. 2004; Walsh et al. 2001) but not by the contracting muscles (Febbraio et al. 2002) although physical exercise induces eHSP70 release, as it was first described in an experiment where subjects followed a 60 -min treadmill at $70 \%$ of maximal oxygen uptake (Walsh et al. 2001). After that, the upregulation of eHSP70 has been observed after prolonged exercise, which appears to rely on the duration and intensity of the exercise (Fehrenbach et al. 2005). Increased levels of eHSP70 have been reported in the circulation of sedentary people after $1 \mathrm{~h}$ of moderate and intensive exercise along with increased neutrophil microbicide capacity and chemotaxis (Ortega et al. 2006; Ortega et al. 2009), suggesting that eHSP70 plays an important role in exercise-induced inflammation and modulation of the innate immune response.

Extracellular HSPs can initiate both innate and adaptive immunity (Johnson and Fleshner 2006; Srivastava 2002). HSPs derived from pathogens or host cells can directly activate or enhance the activity of various innate immune cells to produce cytokines and chemokines (Chen and Cao 2010; Johnson and Fleshner 2006). These proteins promote maturation, migration of antigen-presenting cells (APC), and subsequent $\mathrm{APC}-\mathrm{T}$ cell interaction, thus initiating the adaptive immune response. HSPs can also bind antigenic peptides derived from tumors or viruses and have been applied to vaccine development as adjuvants. According to the "danger signal," theory, immune cells are activated by alarm signals derived from stress or damaged self-proteins (Matzinger 2002). It is accepted that extracellular HSPs fit the criteria for danger signals as they can promote inflammatory cytokine production of APC and initiate antigen-specific immune responses, present antigens to T cells in a "danger" context, and have been linked to the pathogenesis of several autoimmune diseases (Chen and Cao 2010; Millar et al. 2003).

In a previous work of our group, we evaluated the relationship between serum HSP70 immunocontent and oxidant status in sepsis. Patients with severe sepsis were followed up for 28 days after diagnosis or until death. The serum of these septic patients presented augmented HSP70 levels. Analysis of oxidative parameters revealed that septic patients with pronounced oxidative damage in serum had also increased
HSP70 levels, while septic patients with control-like serum oxidative parameters had lower HSP70 levels. Furthermore, an analysis of septic patients according to survival outcome indicated that those patients with higher HSP70 serum levels presented increased mortality, leading to the conclusion that the serum HSP70 levels are being modulated according to the patient oxidant status and increased serum HSP70 levels are associated with mortality in sepsis (Gelain et al. 2011).

It is known that the serum of septic patients is able to induce the activation of macrophages and the production of IL-10; also, the phagocytic indices of these macrophages were correlated with the severity and mortality of the disease (Peck et al. 2009). Murine models of lethal sepsis have higher protein carbonyl levels and an imbalance in SOD/CAT (superoxide dismutase/ catalase) when compared with the nonlethal group, indicating that oxidative stress is exacerbated in the lethal model (Andrades et al. 2005). Thus, it is likely that several proteins related to an anti-inflammatory response undergo oxidation by reactive species and, consequently, their functions change.

Considering that we had previously demonstrated that sepsis is associated with redox imbalance and oxidative stress, the aim of this work was to investigate a possible relationship between previously oxidized HSP70 and the activation of macrophage cells.

\section{Methods}

\section{Preparation of oxidized HSP70}

The treatment used to oxidize HSP was briefly modified from Venereau et al. (2012). Purified bovine HSP70 was purchased from Sigma-Aldrich ${ }^{\circledR}$ (H9776). HSP70 was treated with different concentrations $(1,5,10,25,50$, and $100 \mathrm{mM})$ of the oxidizing agent hydrogen peroxide $\left(\mathrm{H}_{2} \mathrm{O}_{2}\right)$ for $1 \mathrm{~h}$ at $37{ }^{\circ} \mathrm{C}$ under agitation and dialyzed before the addition to cells or other analyses to remove the excess of hydrogen peroxide. The final concentration of HSP70 used in all cell treatment experiments was $1 \mu \mathrm{g} / \mathrm{mL}$.

\section{Polyacrylamide gel electrophoresis}

We added $4 \mu \mathrm{g}$ of protein to $12 \mu \mathrm{L}$ of $\mathrm{H}_{2} \mathrm{O}_{2}$ or Milli-Q water (for control), incubated the mixture at $37^{\circ} \mathrm{C}$ for $1 \mathrm{~h}$, and then maintained it at $-20{ }^{\circ} \mathrm{C}$ for $20 \mathrm{~min}$. Samples were mixed with $16 \mu \mathrm{L}$ of nondenaturing buffer or denaturing buffer and loaded onto $12 \%$ polyacrylamide gel. Electrophoresis followed for approximately $1 \mathrm{~h}$. Gels were stained with Coomassie Blue and digitized.

For the alkylation experiment, $4 \mu \mathrm{g}$ of HSP70 was previously treated with $10 \mathrm{mM}$ of iodoacetamide for $30 \mathrm{~min}$ in the absence of light. After that, samples were lyophilized to 
remove the alkylating agent and resuspended in Milli-Q water. Samples were treated with $\mathrm{H}_{2} \mathrm{O}_{2}$ for $1 \mathrm{~h}$ at $37{ }^{\circ} \mathrm{C}$ and maintained at $-20{ }^{\circ} \mathrm{C}$ for $20 \mathrm{~min}$. A nondenaturing buffer was utilized. Electrophoresis followed for approximately $1 \mathrm{~h}$. Gels were stained with Coomassie Blue and digitized.

\section{Cell culture line macrophage RAW 264.7}

The exponentially growing macrophage-derived cell line RAW 264.7, obtained from the Rio de Janeiro Cell Bank (BCRJ, Rio de Janeiro, Brazil), was maintained in RPMI 1640 media supplemented with $10 \%$ heat-inactivated fetal bovine serum (FBS), $2 \mathrm{mM}$ of glutamine, $0.28 \mu \mathrm{g} / \mu \mathrm{L}$ of gentamicin, and $250 \mu \mathrm{g}$ of amphotericin $\mathrm{B}$, in a humidified atmosphere of $5 \%$ of $\mathrm{CO}_{2}$ in air at $37^{\circ} \mathrm{C}$. The cell medium was replaced every 2 days, and the cells were subcultured once they reached $90 \%$ confluence. These cells were grown in plastic bottles and scrapped when they reached $70-90 \%$ confluence, counted, and plated. Cells were seeded in 96-well plates for DCFH-DA, nitrite production, sulforhodamine B (SRB), and MTT (3-(4, 5-dimethylthiazol-2-yl)-2, 5-diphenyltetrazolium bromide) assays; in 24-well plates for phagocytosis assay; and in 6-well plates for TNF- $\alpha$ release assay. The concentration of HSP70 used in all cell treatment experiments was $1 \mu \mathrm{g} / \mathrm{mL}$.

Nitrite assay

The accumulation of $\mathrm{NO}_{2}^{-}$, a stable end product of $\mathrm{NO}$ formation, in conditioned media was measured as an indicator of $\mathrm{NO}$ production. Cells were seeded in a 96 well plate and then treated with oxidized HSP70 (oxHSP70) or nonoxidized HSP70 (HSP70). One hundred microliters of cell-free conditioned medium was transferred and incubated with $100 \mu \mathrm{L}$ of Griess reagent at $37^{\circ} \mathrm{C}$ for $15 \mathrm{~min}$ and the absorbance measured in a microplate reader at $540 \mathrm{~nm}$ (Li et al. 2002).

\section{SRB assay}

Cells were seeded in a 96-well microplate and then treated with oxHSP70 or HSP70. After removal of the medium, cells were fixed with $10 \%$ trichloroacetic acid for $1 \mathrm{~h}$ at $4{ }^{\circ} \mathrm{C}$ followed by staining for $30 \mathrm{~min}$ with $0.4 \%$ (wt/vol) SRB dissolved in $1 \%$
Fig 1 a Polyacrylamide gel electrophoresis of HSP70 after $1 \mathrm{~h}$ of exposure or not to different concentrations of hydrogen peroxide at $37^{\circ} \mathrm{C}$ under agitation. Samples were mixed in reducing buffer containing $\beta$ -

mercaptoethanol. b Densitometry of the $70-\mathrm{kDa}$ band. $\mathbf{c}$ Densitometry of the $140-\mathrm{kDa}$ band. Representative image of three independent experiments. No statistics applied

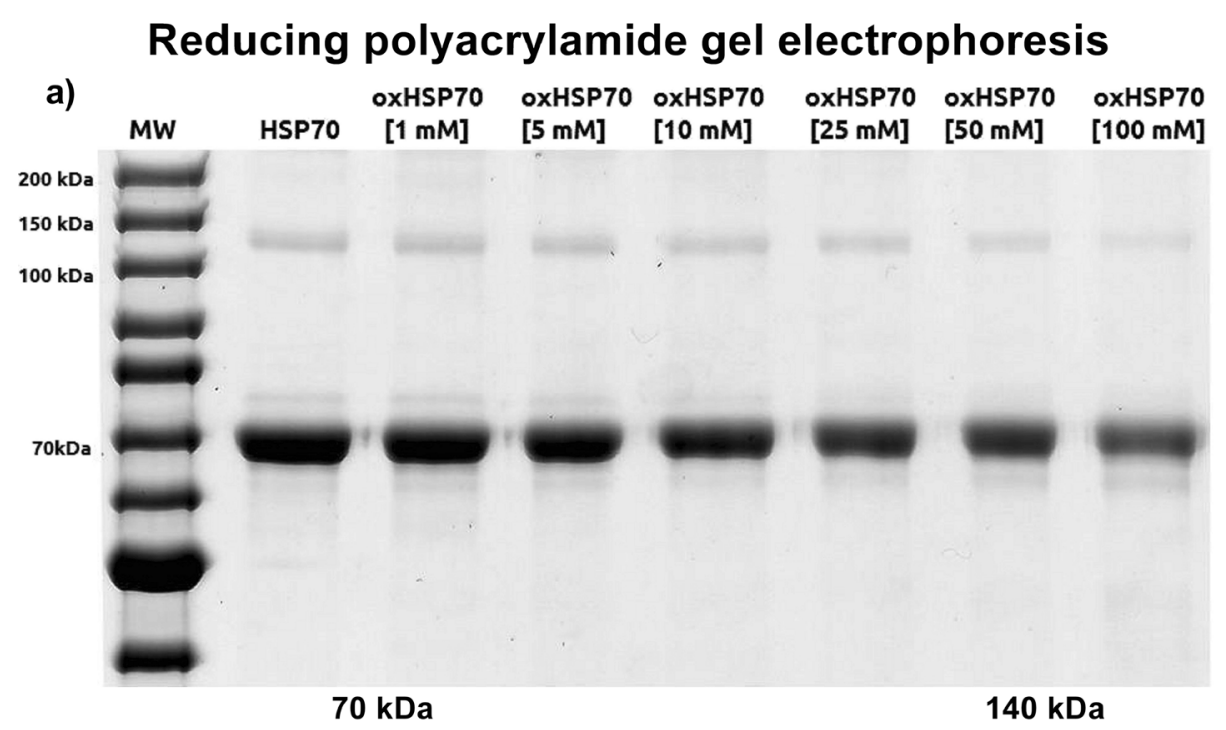

b)

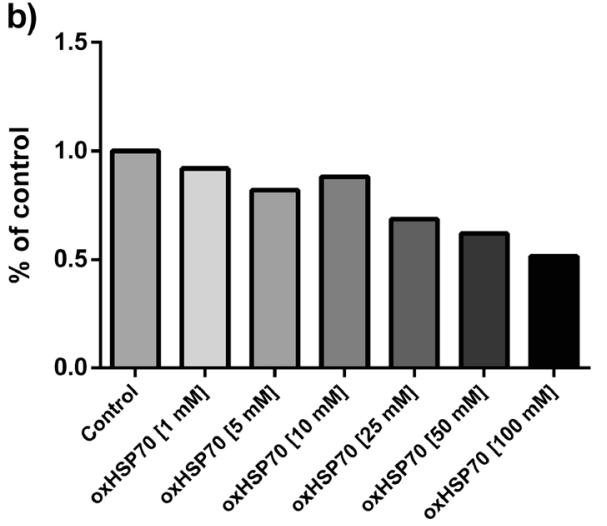

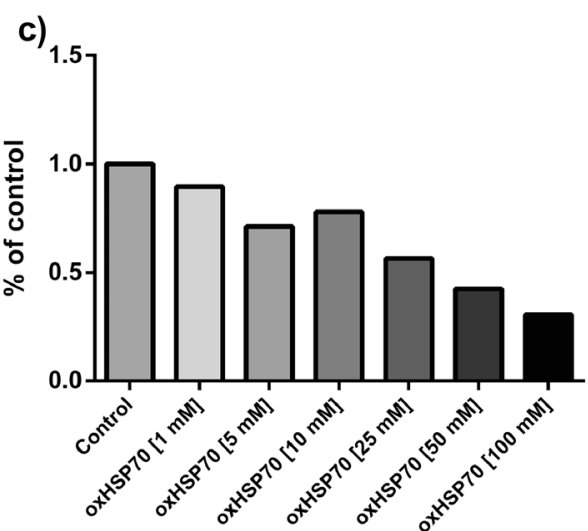


acetic acid. Unbound dye was removed by four washes with $1 \%$ acetic acid, and protein-bound dye was extracted with $10 \mathrm{mM}$ unbuffered Tris base [tris (hydroxymethyl) aminomethane] for determination of optical density in a computer-interfaced, 96well microtiter plate reader at $515 \mathrm{~nm}$ (Skehan et al. 1990).

\section{MTT assay}

Cell viability was measured via MTT assay. RAW 264.7 macrophages were seeded in a 96-well microplate and then treated or not with HSP70 or oxHSP70 for $24 \mathrm{~h}$. The medium was removed, and cells were washed with phosphate-buffered saline (PBS). MTT $(0.05 \mathrm{mg} / \mathrm{mL})$ was added for $1 \mathrm{~h}$ at $37^{\circ} \mathrm{C}$. Cells were again washed, and DMSO was added for $15 \mathrm{~min}$ in the absence of light. Absorbance was read at 560 and $630 \mathrm{~nm}$ (Denizot and Lang 1986).
Phagocytic activity

The modulation of the macrophages' phagocytic activity was assessed by the zimosan particles assay. Zimosan $(1.25 \mathrm{mg})$ was incubated under agitation with neutral red dye $(200 \mathrm{mg} /$ $\mathrm{mL}$, dissolved in DMSO) for $10 \mathrm{~min}$. This preparation was resuspended in 20 volumes of PBS, centrifuged, and washed. The resulting pellet was resuspended in $2.5 \mathrm{~mL}$ of PBS. Fifty microliters of this suspension was mixed with $650 \mathrm{~mL}$ of RPMI 1640 medium. Cells seeded in 24-well plates were incubated with $2 \mathrm{mM}$ of PMA (phorbol 12-myristate 13acetate) or ethanol. After $30 \mathrm{~min}$, the treatments (oxHSP70 or HSP70) were added to the plate for $30 \mathrm{~min}$ in an incubator at $37^{\circ} \mathrm{C}$. After that, $50 \mu \mathrm{L}$ of the preparation of neutral redstained zimosan was added in each well of the plate. The process of phagocytosis lasted $30 \mathrm{~min}$ and then was interrupted by adding cold PBS. The phagocytic

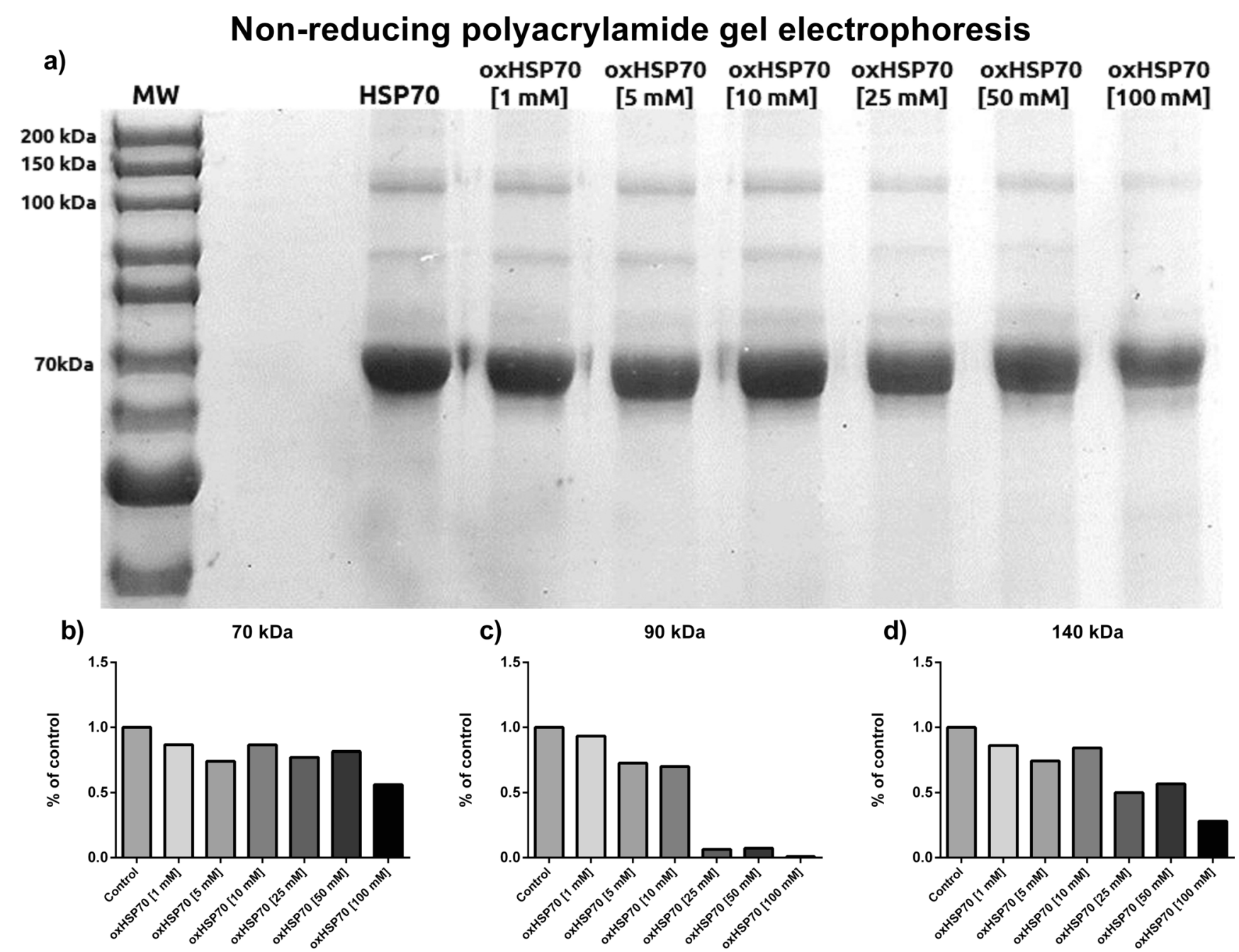

Fig 2 a Polyacrylamide gel electrophoresis of HSP70 after $1 \mathrm{~h}$ of exposure or not to different concentrations of hydrogen peroxide at $37^{\circ} \mathrm{C}$ under agitation. Samples were mixed in a nonreducing buffer to preserve oxidative modifications (without $\beta$-mercaptoethanol). b
Densitometry of the 70-kDa band. c Densitometry of the $90-\mathrm{kDa}$ band. d Densitometry of the $140-\mathrm{kDa}$ band. Representative image of three independent experiments. No statistics applied 
macrophages as well as the particles were counted in the digital microscope IX-81 (Olympus) utilizing the program Cell. The phagocytic index was calculated based on the Hishikawa index (Hishikawa et al. 1991). Briefly, in this system, zimosan particles were scored as phagocytized when they were at the same depth of field as the cell and scored as bound when they were seen to be attached to the cell membrane and either at different depth of field compared with the cell or were seen in profile to be outside the cell membrane. The data were presented as a phagocytic index, which was calculated as follows: (number of zimosan particles phagocytized/number of cells scored) $\times$ percent phagocytizing cells .

\section{ELISA indirect assay for TNF- $\alpha$ release}

The induction of TNF- $\alpha$ release to the incubation medium was quantified by ELISA indirect assay. Cells were seeded in six-well plates and treated for $24 \mathrm{~h}$. After that, $200 \mu \mathrm{L}$ of the medium was transferred to a 96-well ELISA plate for $36 \mathrm{~h}$ for protein adhesion. Following removal of the medium, the plate was washed with TTBS $1 \times$ and $100 \mu$ of $1: 10,000$ antibody anti-TNF- $\alpha$ solution was added for $24 \mathrm{~h}$ at $4{ }^{\circ} \mathrm{C}$. After washing, the plate was incubated with a solution containing the secondary antibody (antirabbit 1:10,000) for $3 \mathrm{~h}$ at room temperature, washed again with TTBS $1 \times$, and added the revelation solution for $30 \mathrm{~min}$. The reaction was stopped with sulfuric acid, and the absorbance was read at $450 \mathrm{~nm}$ in a microplate reader.

\section{Annexin $\mathrm{V}$ binding assay}

Cells were seeded in six-well plates and then treated or not with HSP70 or oxHSP70 for $24 \mathrm{~h}$. Annexin V binding assay was performed with an Annexin V-FITC Apoptosis Detection Kit from Sigma ${ }^{\circledR}$. Cells were analyzed in a FACSCalibur flow

\section{Alkylation followed by oxidation Polyacrylamide gel electrophoresis}

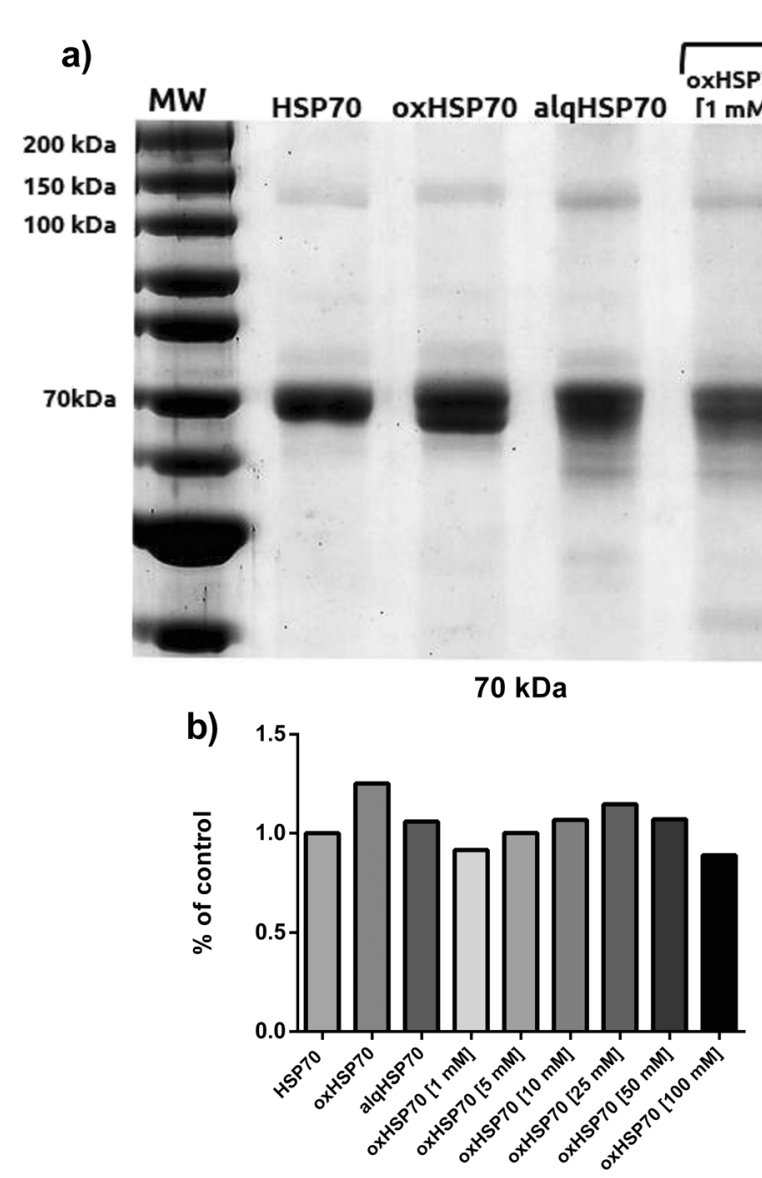

Fig 3 a Polyacrylamide gel electrophoresis of HSP70 pretreated or not with iodoacetamide for $1 \mathrm{~h}$ then exposed for $1 \mathrm{~h}$ to different concentrations of hydrogen peroxide at $37^{\circ} \mathrm{C}$ under agitation. Samples were mixed in a nonreducing buffer to preserve alkylating and oxidizing
HSP70 alkylated then oxidized

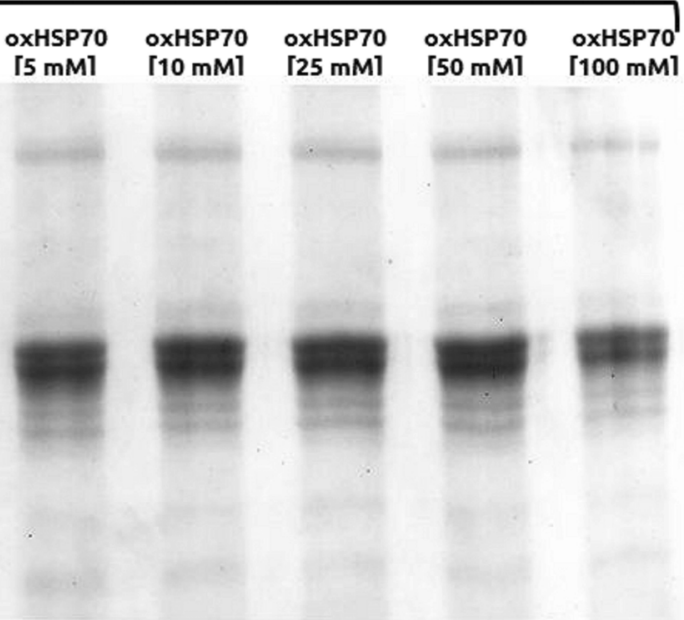

$140 \mathrm{kDa}$

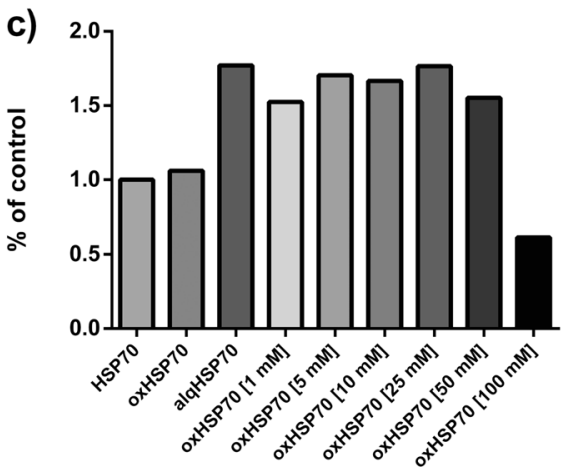

modifications (without $\beta$-mercaptoethanol). b Densitometry of the 70 $\mathrm{kDa}$ band. $\mathbf{c}$ Densitometry of the $140-\mathrm{kDa}$ band. Representative image of three independent experiments. No statistics applied 
cytometer (BD PharMingen). Viable (annexin-/PI-), apoptotic (annexin+/PI-), necrotic nonviable (annexin-/PI+), or late apoptotic/necrotic (annexin+/PI+) cells were characterized as described in Zanotto-Filho et al. (2012).

\section{Results}

In order to elucidate the role of oxidation in the possible structural modifications HSP70 may undergo, we treated purified HSP70 with different concentrations of hydrogen peroxide and submitted it to polyacrylamide gel electrophoresis. In the presence of a reducing agent, the protein showed as a major band of $70 \mathrm{kDa}$, as expected. However, we observed a decrease in the intensity of this band as the concentration of hydrogen peroxide increased. The electrophoretic analysis also showed a $140-\mathrm{kDa}$ band that probably was the dimerized form of HSP70. This band showed the same behavior as the main $70-\mathrm{kDa}$ band, presenting a decrease in its intensity as the hydrogen peroxide concentration increased (Fig. 1).

In an oxidizing environment, proteins with cysteine residues tend to form inter- and intramolecular disulfide bonds, which are reversed by a reducing agent. To eliminate this interfering condition, we utilized a sample buffer without $\beta$ mercaptoethanol (Fig. 2). Here, the predominant band was the $70-\mathrm{kDa}$ one, which faded in intensity as the $\mathrm{H}_{2} \mathrm{O}_{2}$ concentration increased. The $140-\mathrm{kDa}$ band presented the same pattern. In addition, there was a $90-\mathrm{kDa}$ band that was observed in

\section{RAW 264.7 Macrophage nitrite production}

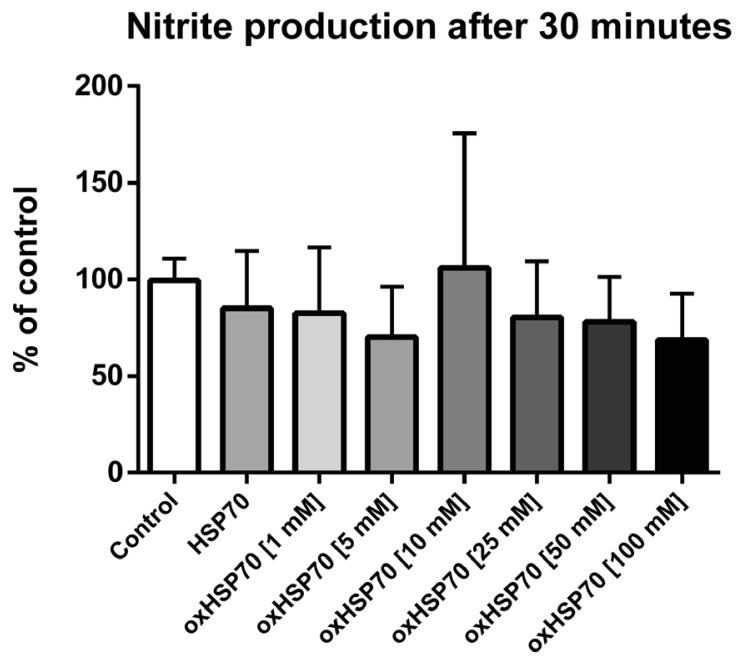

Nitrite production after 120 minutes

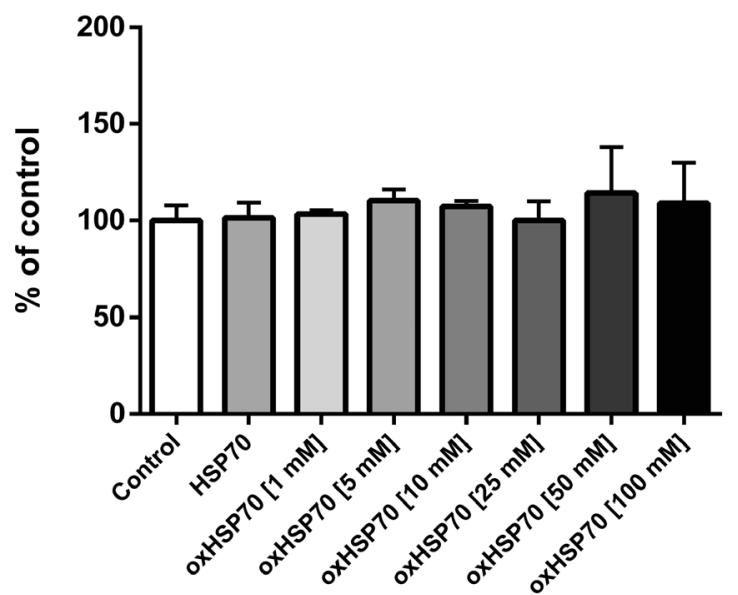

Fig 4 Nitrite production by RAW 264.7 macrophages after 30, 60, and $120 \mathrm{~min}$ and $24 \mathrm{~h}$ of exposition or not to HSP70 (nonoxidized) and to oxHSP70 (oxidized HSP70 by different concentrations of $\mathrm{H}_{2} \mathrm{O}_{2}$ for $1 \mathrm{~h}$ at
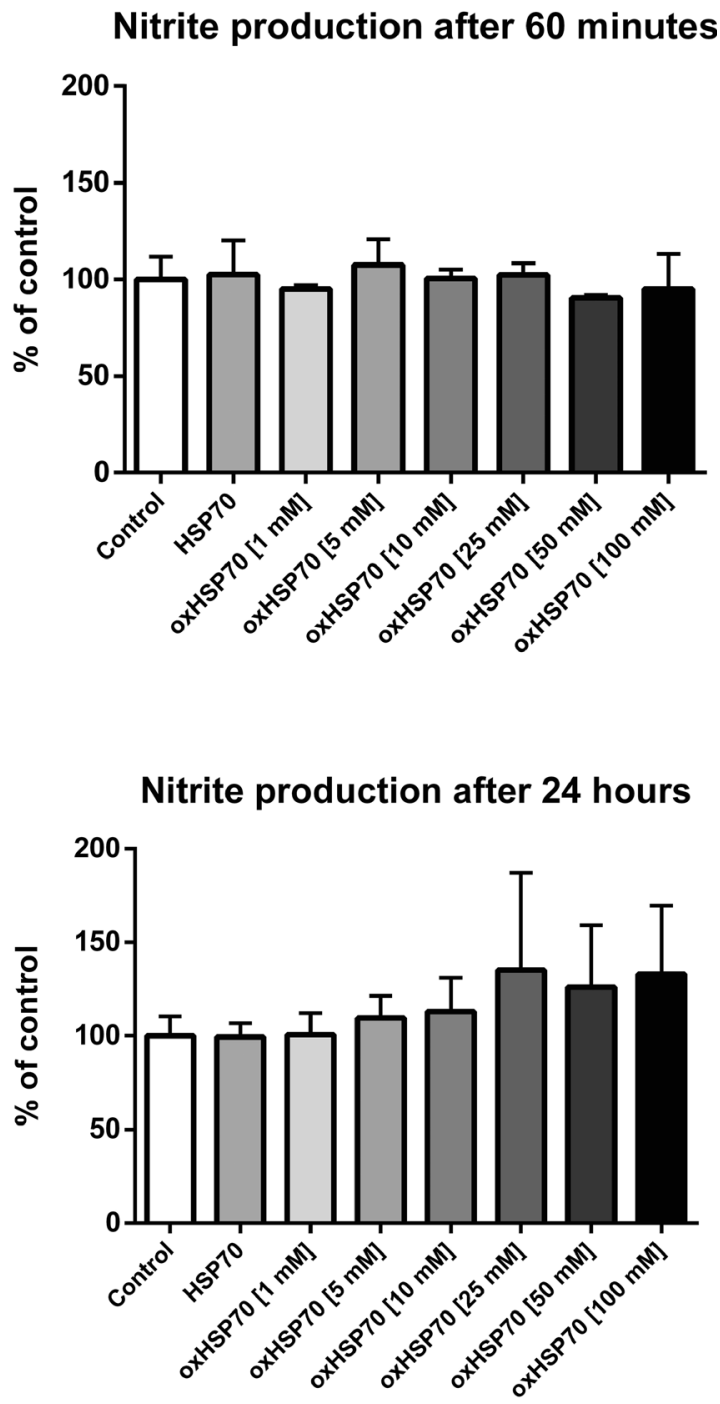

$37^{\circ} \mathrm{C}$ ). Experiments were triplicated, and data are present as mean (SD). One-way ANOVA was performed followed by Tukey's post hoc test. No significant differences between treatments were observed. $P<0.05$ 
these conditions which also presented the pattern of decreased intensity as the $\mathrm{H}_{2} \mathrm{O}_{2}$ concentration increased. Although all the bands decreased, the decrease was not as smooth as that in the reducing gel.

If the nonreducing gel has a different pattern than the reducing one, could it be due to the disulfide bonds or the interactions caused by the prooxidizing environment? Moreover, are these interactions important to the correct folding of the protein? When pretreated with an alkylating agent and then treated or not with hydrogen peroxide, the major 70-kDa band was split into two minor bands (Fig. 3). In addition, bands in the range of $60 \mathrm{kDa}$ were visualized, suggesting that the protein was not completely and correctly assembled. This could also be due to partial degradation of alkylated HSP70. This electrophoretic profile differs from the previous two profiles. The $70-\mathrm{kDa}$ band did not decrease in intensity with increasing concentrations of hydrogen peroxide. The $140-\mathrm{kDa}$ bands decreased with intensity only at the highest concentration used. These same treatments were used to investigate the cellular response that oxHSP70 could trigger in macrophages. RAW 264.7 cells were incubated with oxHSP70 for 30, 60, and $120 \mathrm{~min}$ and $24 \mathrm{~h}$, after which the nitrite production and cell viability were evaluated. We observed no significant differences in nitrite production on any periods of incubation (Fig. 4).

\section{RAW 264.7 Macrophage Cell Proliferation}

Cell proliferation after $\mathbf{3 0}$ minutes

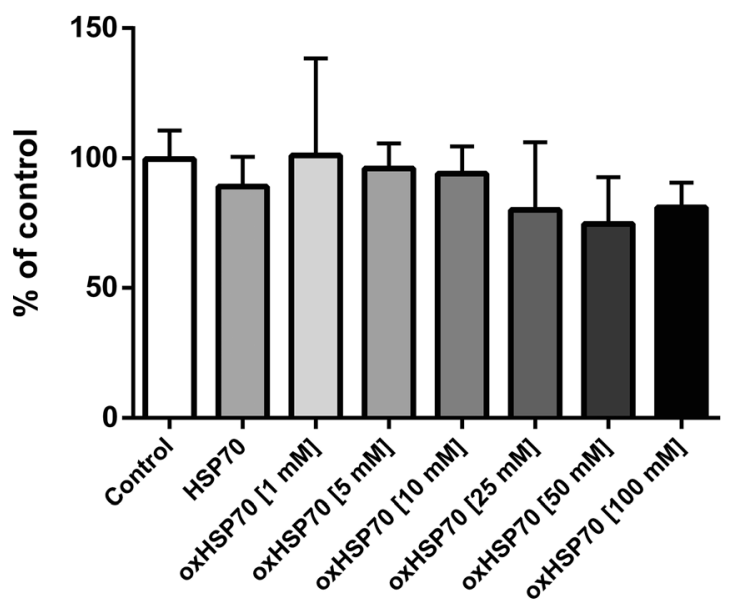

Cell proliferation after 120 minutes

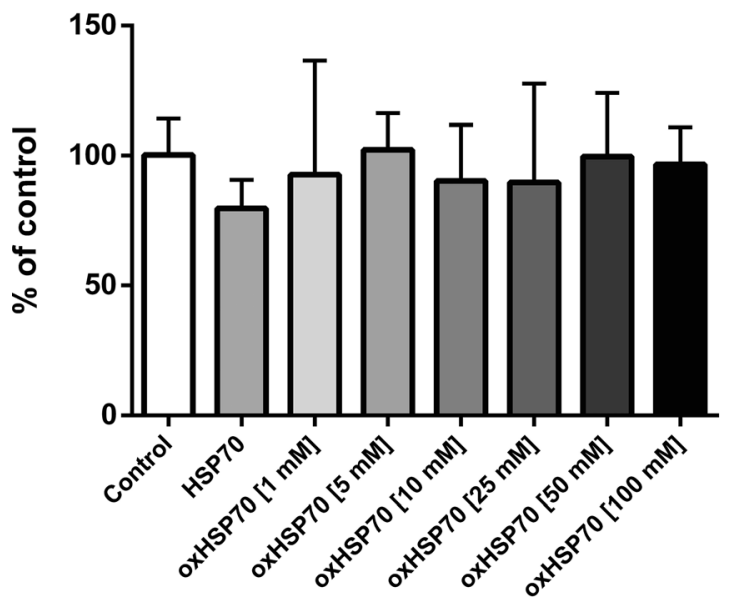

Fig 5 Measurement of RAW 264.7 macrophages cell proliferation after 30,60 , and $120 \mathrm{~min}$ and $24 \mathrm{~h}$ of exposition or not to HSP70 (nonoxidized) and to oxHSP70 (oxidized HSP70 by different concentrations of $\mathrm{H}_{2} \mathrm{O}_{2}$ for $1 \mathrm{~h}$ at $37^{\circ} \mathrm{C}$ ). Experiments were triplicated, and data are presented as
Cell proliferation after $\mathbf{6 0}$ minutes

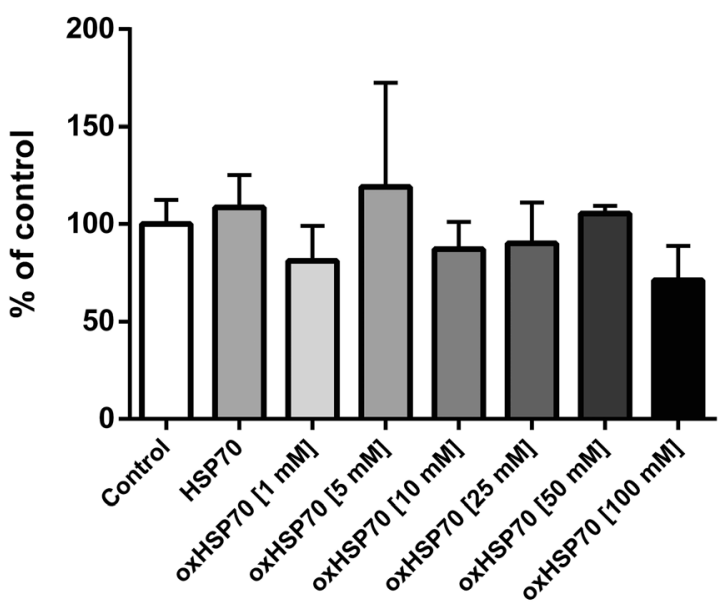

Cell proliferation after 24 hours

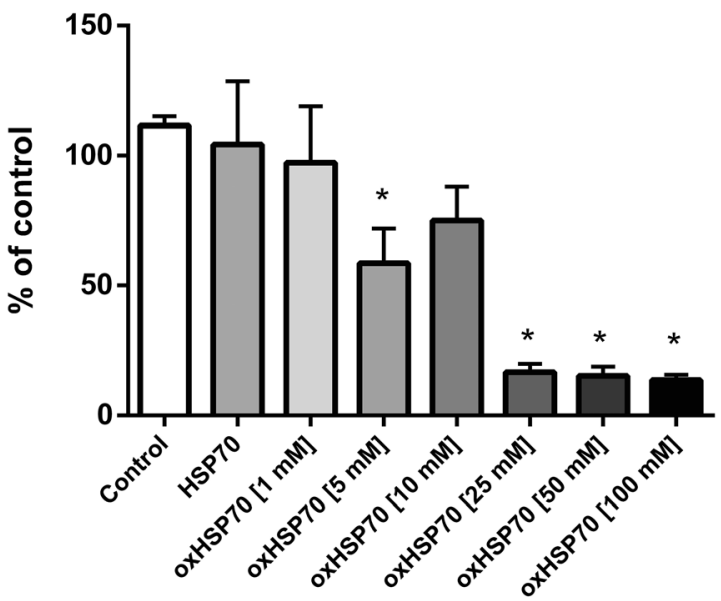

mean (SD). One-way ANOVA was performed followed by Tukey's post hoc test. HSP70 oxidized by 5, 25, 50, and $100 \mathrm{mM}$ of $\mathrm{H}_{2} \mathrm{O}_{2}$ differed significantly from control (nontreated) and from HSP70 nonoxidized. $P<0,05$ 
To assess cell survival, we used the SRB staining assay as a parameter of cell number, and no significant differences were observed at 30, 60, and 120 min of exposure. However, after $24 \mathrm{~h}$ of exposure, we observed that the HSP70 oxidized with $5,25,50$, and $100 \mathrm{mM}$ of hydrogen peroxide induced a decrease in SRB staining compared to the control $(P<0.05)$, indicating a decrease in the number of cells (Fig. 5).

To further explore the effect of oxHSP70 on cell numbers, we decided to evaluate the effect of oxHSP70 on a parameter of cell viability. For this purpose, we performed an MTT reduction assay to evaluate cell viability after treatment with either HSP70 or oxHSP70 for the same period. MTT reduction in cells treated with HSP70 was not different from that in the control (not treated cells), while cells treated with oxHSP70 $\left(10,25,50\right.$, and $100 \mathrm{mM}$ of $\left.\mathrm{H}_{2} \mathrm{O}_{2}\right)$ had decreased MTT reduction compared to HSP70-treated cells and control $(P<0.05)$ (Fig. 6), suggesting oxHSP70 affected cell viability.

After $24 \mathrm{~h}$ of treatment with oxHSP70, the proliferation and viability of the cells decreased, but the nature of this loss was still necessary to clarify. We decided to evaluate the effect of oxHSP70 on cell viability by performing an annexin V binding assay. Cells treated with HSP70 oxidized with 1, 5, 10,25 , and $50 \mathrm{mM}$ of $\mathrm{H}_{2} \mathrm{O}_{2}$ showed no significant changes relative to both the control and HSP70 groups, contrasting with the increase in necrotic populations induced by HSP70 oxidized by $100 \mathrm{mM} \mathrm{H}_{2} \mathrm{O}_{2}$ (Fig. 7).

We next evaluated the effect of oxHSP70 on the modulation of phagocytosis. RAW 264.7 cells were treated for $30 \mathrm{~min}$ with oxHSP70 or HSP70, and then, the phagocytic activity was assessed by the zimosan-based assay. As expected, we observed that HSP70 induced an increase in the score of the Hishikawa index (that is, the higher the index, the higher the activation of the phagocytic activity) when compared to the control; oxHSP70 was not able to induce the same effect as normal HSP70, indicating that oxidation of HSP70 altered its effect on phagocytosis $(P<0.05)$ (Fig. 8).

Another classical parameter of macrophage activation, the secretion of the cytokine TNF- $\alpha$, was assessed. RAW 264.7 macrophages were treated with HSP70 or oxHSP70 for $24 \mathrm{~h}$, and the levels of TNF- $\alpha$ were evaluated by indirect ELISA. As expected, HSP70 induced a significant increase in TNF- $\alpha$ release by RAW 264.7 cells, while oxHSP70 failed to induce this effect $(P<0.05)$ (Fig. 9). This result also indicated that oxidation of HSP70 induced a loss of the extracellular signaling function of this protein.

\section{Discussion}

Many years have passed since the discovery of HSP70; nowadays, research has shown that its functions and roles are much wider than its chaperone activity. Recently, these proteins have been identified in the serum after diverse forms of stress (heavy exercise, inflammatory process, septic shock, and trauma) (Kindas-Mugge et al. 1993; Trautinger et al. 1996a; Trautinger et al. 1996b). First, it was thought that its presence was caused by the necrotic disruption of the cell membrane and consequently extravasation of cytosolic proteins. After that, it was shown that HSP70 could be actively

\section{RAW 264.7 Macrophage cell viability after 24 hours}

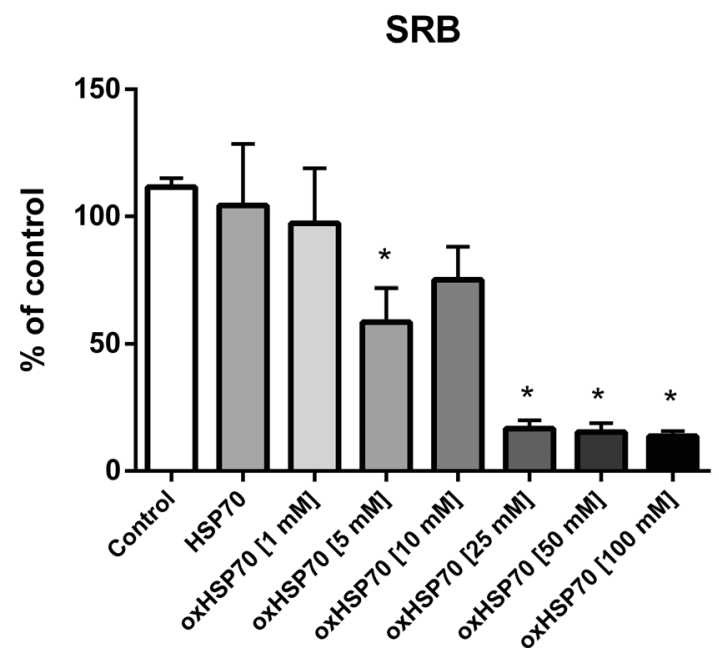

Fig 6 Measurement of RAW 264.7 macrophages cell viability after $24 \mathrm{~h}$ of exposition or not to HSP70 (nonoxidized) and to oxHSP70 (oxidized HSP70 by different concentrations of $\mathrm{H}_{2} \mathrm{O}_{2}$ for $1 \mathrm{~h}$ at $37^{\circ} \mathrm{C}$ ). Experiments were triplicated, and data are presented as mean (SD). $24 \mathrm{~h} \mathrm{SRB}$ placed by side for comparison. One-way ANOVA was performed followed by

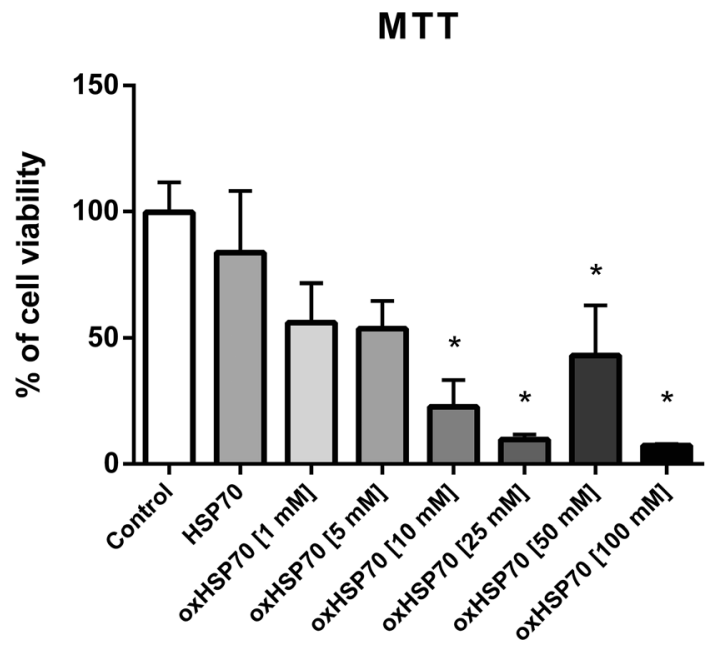

Tukey's post hoc test. All oxHSP70 treatments showed lower cell viability when compared to control, but only HSP70 oxidized by 10, 25, 50, and $100 \mathrm{mM}$ of $\mathrm{H}_{2} \mathrm{O}_{2}$ differed significantly from control (nontreated) and from HSP70 nonoxidized. $P<0.05$ 

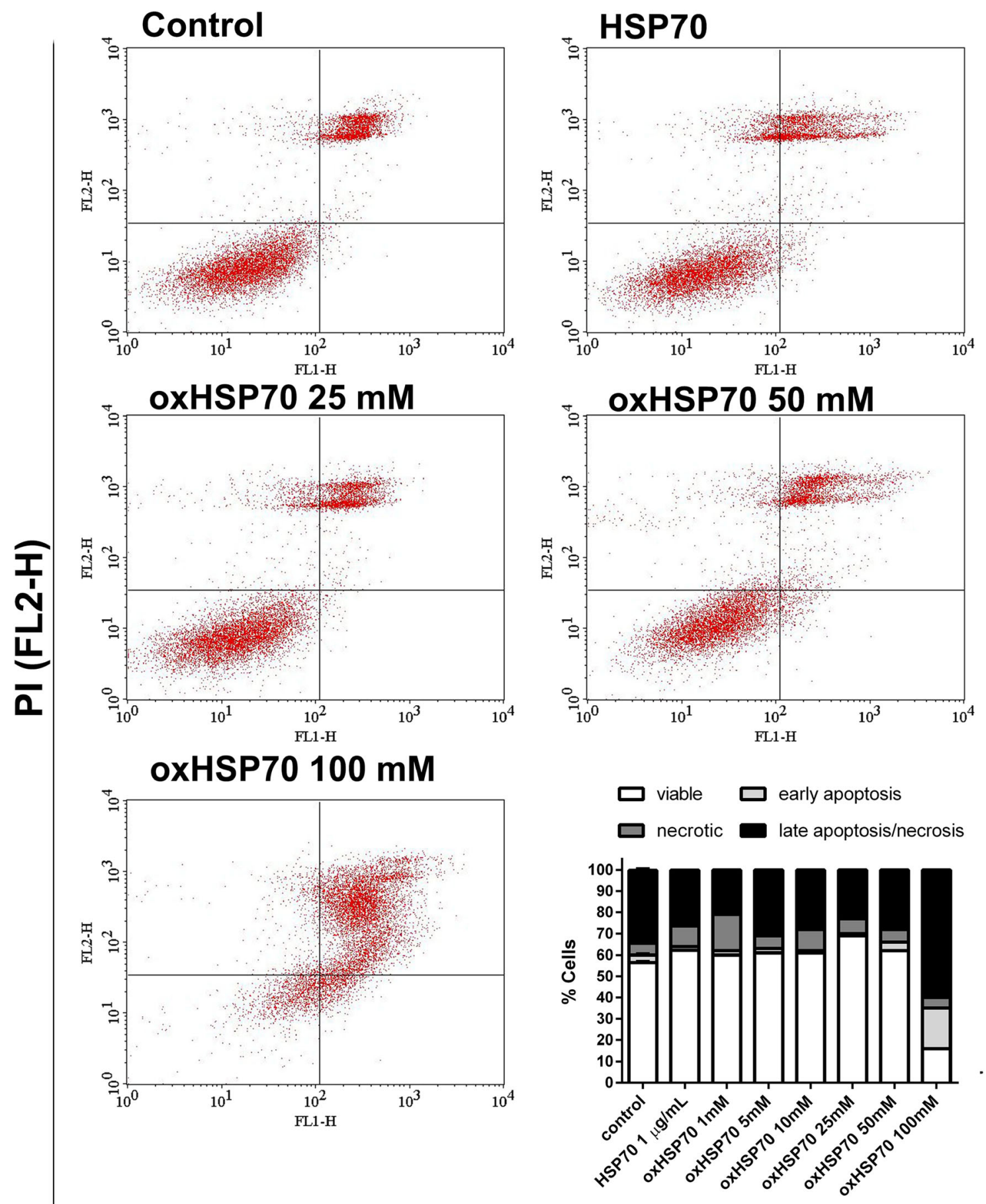

\section{Annexin V-FITC (FL1-H)}

Fig 7 FACS annexin V binding assay. Graphical representation of the annexin V binding assay results. Viable (annexin-/PI-), apoptotic (annexin+/PI-), necrotic nonviable (annexin-/PI+), or late apoptotic/necrotic (annexin+/PI+) cells were characterized

secreted from the intracellular environment to the extracellular space (Vega et al. 2008; Hightower and Guidon 1989), leading to the belief that they could have a deeper signaling role during pathogenic processes.

In a recent study by our group (Gelain et al. 2011), we have shown the correlation between the clinical outcome of septic patients and the presence of HSP70 in their serum. More than that, the patients that died had more oxidative stress levels in their serum and also had increased HSP70 serum levels. Herein, we submitted purified HSP70 to oxidation and evaluated structural changes in the protein and the effects of oxHSP70 on cell viability and immunomodulatory properties. 
Fig 8 a Modulation of phagocytic activity of RAW 264.7 macrophages exposed or not to HSP70 (nonoxidized) and to oxHSP70 (oxidized HSP70 by different concentrations of $\mathrm{H}_{2} \mathrm{O}_{2}$ for $1 \mathrm{~h}$ at $37^{\circ} \mathrm{C}$ ). Experiments were triplicated, and data are presented as mean (SD). Twoway ANOVA was performed. HSP70 nonoxidized differed significantly from control (nontreated) and from oxHSP70, showing a higher phagocytic index. $P<0.05$. b Representative images of the treatment's effect on macrophage phagocytosis

\section{RAW 264.7 Macrophage Phagocytic Activity}

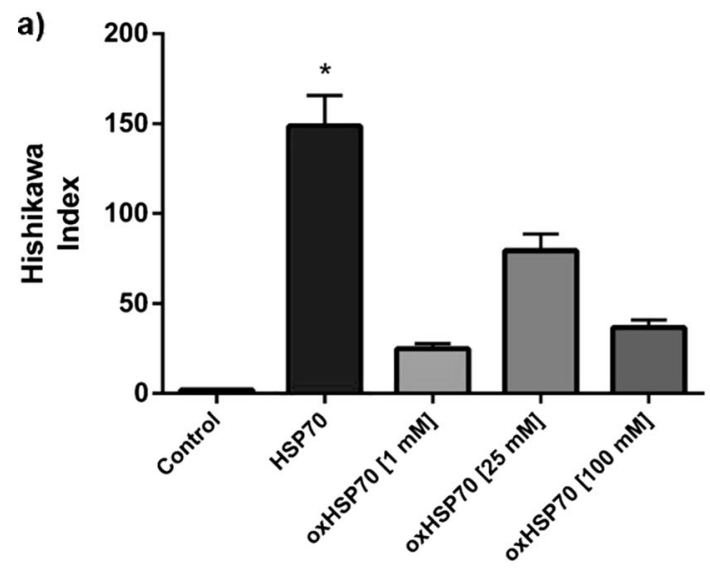

b)

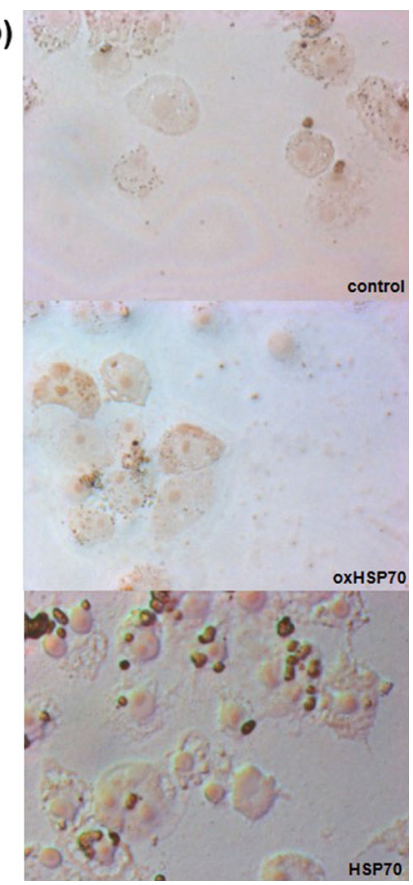

When submitted to an oxidative agent (hydrogen peroxide), HSP70 showed some alterations in its electrophoretic profile when exposed to a reducing sample buffer. The major protein band of $70 \mathrm{kDa}$ and the $140-\mathrm{kDa}$ band (the probable dimer form of the protein) decreased in intensity as the gradient levels of oxidation increased, suggesting that the oxidative environment either damaged the protein or oxidized specific residues, changing the protein's conformation (Fig. 1). In nonreducing conditions, electrophoresis of both normal and oxidized HSP70 evidenced a 90-kDa band, which was not apparent in the gel under reducing conditions. Although we do not know what process caused the appearance of this $90-\mathrm{kDa}$ band in both electrophoretic separations, it is very likely that this process is a redox-related modification, such as disulfide bond formation, since this band was decreased in HSP70 submitted to higher levels of $\mathrm{H}_{2} \mathrm{O}_{2}$. Thus, we suggest that this $90-\mathrm{kDa}$ band visualized in the gel under reducing conditions is an intermediate, redox-modified form of HSP70 (Fig. 2).

As formation of intramolecular or intermolecular disulfide bonds is one of the most notable modifications of proteins containing cysteine residues, we blocked the possible sites for disulfide formation by pretreating HSP70 with an alkylating agent, iodoacetamide (IAA); so, when the protein was incubated with hydrogen peroxide, any possible disulfide bonds could not be formed. Here, we can observe that the intensity of the bands was different when comparing both reducing and nonreducing conditions. The $70-$ and $90-\mathrm{kDa}$ bands did not decrease in the same manner. Their intensities were more constant with the increase in the oxidant levels, leading to the possibility of a cysteine oxidation role; also, the electrophoretic profile formed by running HSP70 in this condition showed a splitting of the $70-\mathrm{kDa}$ band, suggesting that this major band was actually formed by bands of very close molecular weight (Fig. 3).

Overall, our results are similar to the findings of Callahan et al. (2002), where HSP70 showed a differential acquisition of antigenic peptides under oxidative condition and a gain of secondary structures (Callahan et al. 2002); Cumming et al.

\section{RAW 264.7 Macrophages TNF- $\alpha$ production}

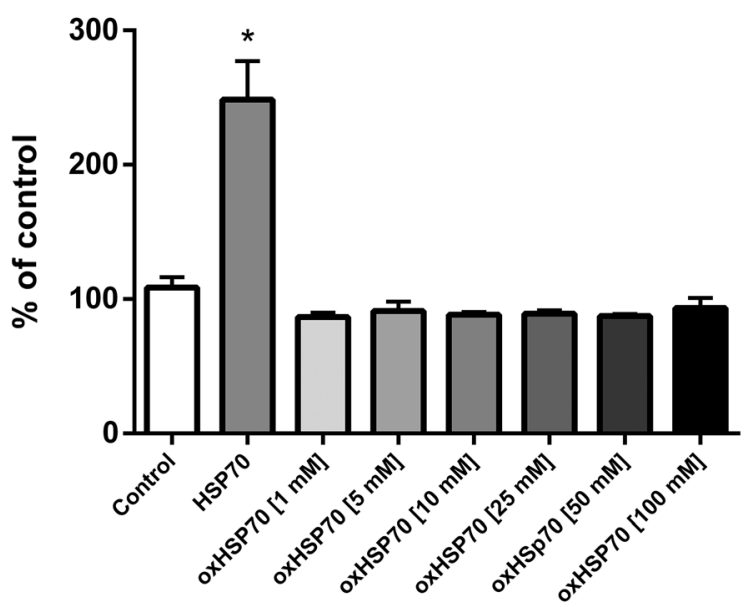

Fig 9 Modulation of RAW 264.7 macrophages TNF- $\alpha$ production after exposition or not to HSP70 (nonoxidized) and to oxHSP70 (oxidized $\mathrm{HSP} 70$ by different concentrations of $\mathrm{H}_{2} \mathrm{O}_{2}$ for $1 \mathrm{~h}$ at $37^{\circ} \mathrm{C}$ ). Experiments were triplicated, and data are presented as mean (SD). One-way ANOVA was performed followed by Tukey's post hoc test. HSP70 nonoxidized differed significantly from control (nontreated) and from oxHSP70, showing a higher TNF- $\alpha$ production. $P<0.05$ 
2004 also demonstrated that during oxidative stress HSP70 can form mixed disulfide bonds, resulting in the dimer with $140 \mathrm{kDa}$ or even a higher molecular weight oligomer (Cumming et al. 2004).

If extracellular HSP70 plays a role in inflammatory processes, and these are commonly associated with oxidative unbalance and stress, what are the effects of a possible oxidation of oxHSP70 on macrophages? To answer this question, we treated RAW 264.7 cells by $30,60,120$, and $24 \mathrm{~h}$ with HSP70 pretreated or not with hydrogen peroxide. We did not observe any significant differences between the production of nitrite by cells treated with oxHSP70 or HSP70, and cell proliferation quantified through the SRB assay did not change during these short treatment times. However, after $24 \mathrm{~h}$ of exposure, we observed an interesting effect. Preoxidized HSP70 diminished the proliferation and viability of the cells as compared to nontreated cells and cells treated with nonoxidized HSP70. Analyses made by flow cytometry showed that cells treated with oxHSP70 oxidized with 1, 5, 10,25 , and $50 \mathrm{mM}$ of $\mathrm{H}_{2} \mathrm{O}_{2}$ presented an annexin $\mathrm{V}$ binding profile similar to both control and HSP70 groups; the majority of the cells were viable, suggesting that oxHSP70 exerted a cytostatic effect. Cells treated with oxHSP70 oxidized with $100 \mathrm{mM}$ showed a large necrotic population, suggesting a cytotoxic effect (Fig. 7).

Also interesting was the observation that the phagocytic activity of the macrophages was diminished in cells treated with preoxidized HSP70 as compared to the cells treated with nonoxidized HSP70, suggesting that oxHSP70 did not activate macrophages with the same efficacy as the nonoxidized HSP70 (Fig. 8).

HSP70 has the ability to induce macrophage activation; one of the parameters observed when this event occurs is the production of inflammatory cytokines, such as IL-8, IL-10, and TNF- $\alpha$. We treated RAW 264.7 macrophages with HSP70 or oxHSP70 for $24 \mathrm{~h}$ and analyzed the content of TNF- $\alpha$ in the incubation medium. The groups treated with oxHSP70 had similar TNF- $\alpha$ levels to the control group; besides, TNF- $\alpha$ release by cells treated with normal HSP70 was increased compared to both oxHSP70-treated and control cells, suggesting that oxHSP70 failed to activate macrophages in a classical way. It is known that TNF- $\alpha$ plays an important role in the proliferation, apoptosis, and differentiation of macrophages. Long-term survival of macrophages is dependent on autocrine signaling by TNF- $\alpha$ (Lombardo et al. 2007). Because TNF- $\alpha$ mediates many of the pathological effects of LPS-TLR4 in conditions such as septic shock, it is suggested that prolonged macrophage survival mediated by TNF- $\alpha$ plays an important role in sepsis (Conte et al. 2006). This can be related to our findings, which showed that after $24 \mathrm{~h}$ of treatment with oxHSP70, RAW 264.7 macrophages produced lower levels of TNF- $\alpha$ (Fig. 6) and had lower cell viability (Fig. 10).

In a general way, HSP70 can be released to the extracellular space as a "danger signal" to the system, as it can be recognized by TLR and triggers a proinflammatory signaling

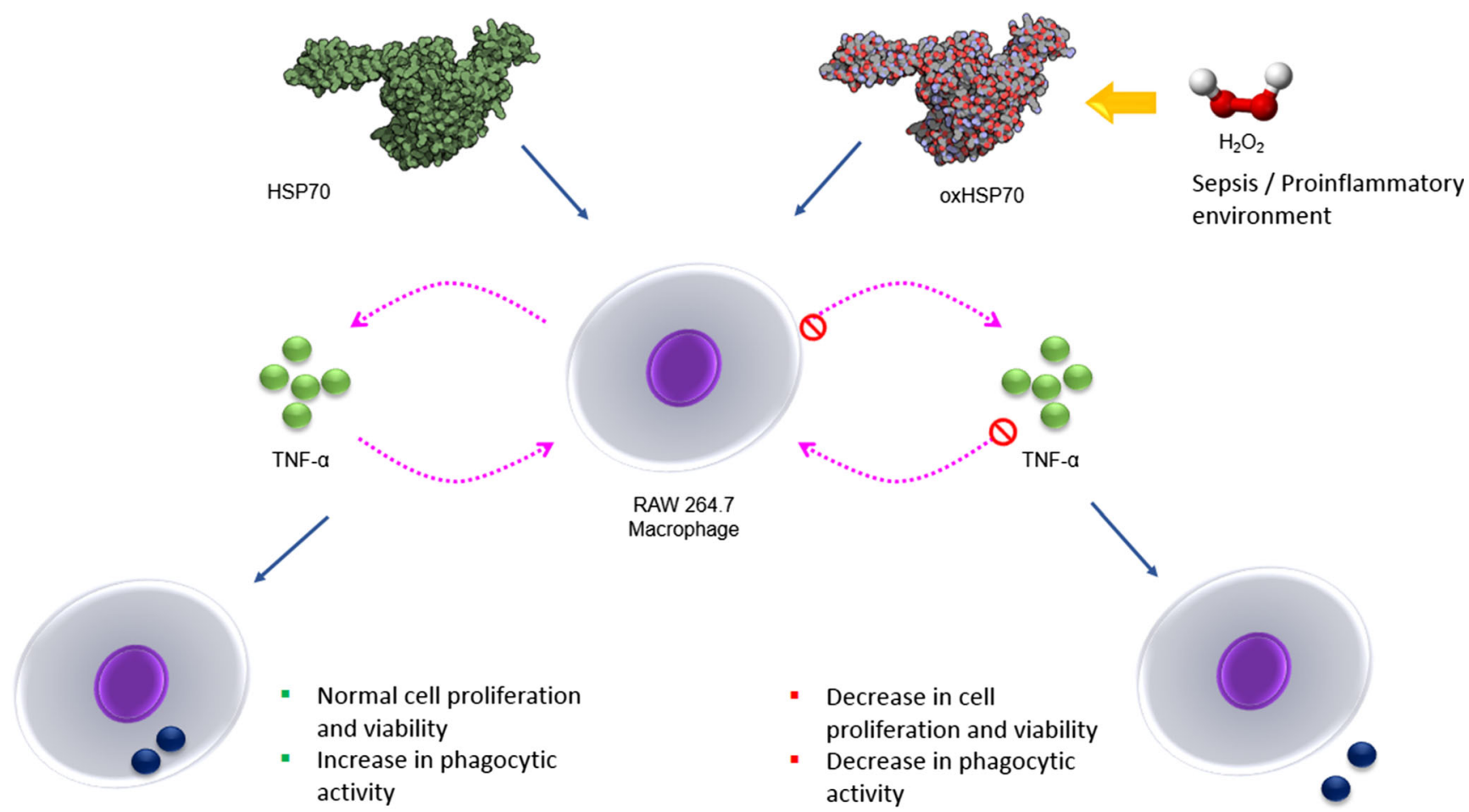

Fig 10 Graphical abstract summarizing the effects of extracellular oxHSP70 on RAW 264.7 macrophage cells on a proinflammatory environment and comparing them to the effects of HSP70 
pathway. Proteins characterized as danger signals are known as DAMPS (damage-associated molecular-pattern). In this context, we can infer that the oxidation and subsequent modification and/or impairment of HSP70 can be related to a lack of this "danger signal" when necessary. Recently, it was shown that HMGB1 works as a DAMP and has different redox forms that are responsible for promoting cell recruitment or proinflammatory cytokine release in a similar fashion as the oxidized HSP70 (Venereau et al. 2012). Luong et al. (2012) showed that the stimulation of TLR4 by HSP70 requires structural integrity of the protein; treating HSP70 with proteinase $\mathrm{K}$-agarose digestion lowers the stimulatory capacity of the protein, and this result corroborates the observation that HSP70 acts as a DAMP and with our data (Luong et al. 2012). Moreover, oxHSP70 could be exerting its effects by activating receptors other than TLR, such as the receptor for advanced end-glycation products (RAGE), a key pattern recognition receptor capable of binding a diverse repertoire of soluble and cell-associated molecules involved in the host response to tissue injury, infection, and inflammation. In a recent study (Ruan et al. 2010), it was shown that HSP70 is a possible novel ligand for RAGE. Ligation of RAGE induces the activation of multiple signaling pathways. These pathways may vary depending on the ligand along with the cell and tissue microenvironment, thus mediating diverse cellular responses, possibly the one triggered by oxHSP70.

Nevertheless, it is important to note that the immune effects of HSP may vary depending on several factors including the specific HSP family (HSP60, HSP70, HSP90), the cellular source of the HSP (normal, cancerous, viral-infected, bacterial), cellular location (intracellular, cell surface, serum), and the physiological circumstances modulating HSP expression (oxidative stress, bacterial infection, viral infection, physical stress). Thus, the specific physiological context of these proteins greatly affects their function, preventing any global statements about the in vivo, immunological functions of HSP70 (Johnson and Fleshner 2006).

Taking into account the results presented in this paper and in our previous findings, we suggest that in a prooxidant situation, common to proinflammatory pathologic processes, HSP70 may undergo structural changes that could lead to functional impairment. As we observed before in septic patients, when there is an increase in serum oxidative damage, there is an increase in pathological aggressiveness, even resulting in death (Gelain et al. 2011). In the present paper, we showed that oxidized HSP70 induced a decrease in phagocytic activity, a decrease in TNF- $\alpha$ production, and a decrease in RAW 264.7 macrophage numbers after $24 \mathrm{~h}$ of treatment. Cytostatic and cytotoxic effects varied with the oxidative gradient to which the protein was exposed. We believe that this may be correlated with the worst outcome observed in our previous work.
Acknowledgments We are grateful to the National Council for Scientific and Technological Development of the Federal Republic of Brazil (CNPq Universal 472225/2011-1), CAPES (PROCAD 066/2007), FAPERGS (PqG 1008860, PqG 1008857, ARD11/1893-7, PRONEX 1000274), PROPESQ-UFRGS, and IBN-Net \#01.06.0842-00. We also would like to express our gratitude to Professor Celia R. Carlini, from LAPROTOX, Department of Biophysics and Center of Biotechnology, Institute of Biosciences, Federal University of Rio Grande do Sul.

\section{References}

Andrades M, Ritter C, Moreira JCF, Dal-Pizzol F (2005) Oxidative parameters differences during non-lethal and lethal sepsis development. J Surg Res 125(1):68-72. doi:10.1016/j.jss.2004.11.008

Asea A (2007) Hsp72 release: mechanisms and methodologies. Methods 43(3):194-198. doi:10.1016/j.ymeth.2007.06.002

Asea A, Kraeft SK, Kurt-Jones EA, Stevenson MA, Chen LB, Finberg RW, Koo GC, Calderwood SK (2000) HSP70 stimulates cytokine production through a CD14-dependant pathway, demonstrating its dual role as a chaperone and cytokine. Nat Med 6(4):435-442. doi: $10.1038 / 74697$

Asea A, Rehli M, Kabingu E, Boch JA, Bare O, Auron PE, Stevenson MA, Calderwood SK (2002) Novel signal transduction pathway utilized by extracellular HSP70: role of toll-like receptor (TLR) 2 and TLR4. J Biol Chem 277(17):15028-15034. doi:10.1074/jbc. M200497200

Barreto A, Gonzalez JM, Kabingu E, Asea A, Fiorentino S (2003) Stressinduced release of HSC70 from human tumors. Cell Immunol 222(2):97-104

Callahan MK, Chaillot D, Jacquin C, Clark PR, Ménoret A (2002) Differential acquisition of antigenic peptides by Hsp70 and Hsc70 under oxidative conditions. J Biol Chem 277(37):33604-33609. doi:10.1074/jbc.M202890200

Chen T, Cao X (2010) Stress for maintaining memory: HSP70 as a mobile messenger for innate and adaptive immunity. Eur J Immunol 40(6): 1541-1544. doi:10.1002/eji.201040616

Conte D, Holcik M, Lefebvre CA, Lacasse E, Picketts DJ, Wright KE, Korneluk RG (2006) Inhibitor of apoptosis protein cIAP2 is essential for lipopolysaccharide-induced macrophage survival. Mol Cell Biol 26(2):699-708. doi:10.1128/MCB.26. 2.699-708.2006

Cumming RC, Andon NL, Haynes PA, Park M, Fischer WH, Schubert D (2004) Protein disulfide bond formation in the cytoplasm during oxidative stress *, 279(21):21749-21758. doi:10.1074/jbc. M312267200

Denizot F, Lang R (1986) Rapid colorimetric assay for cell growth and survival. Modifications to the tetrazolium dye procedure giving improved sensitivity and reliability. J Immunol Methods 89(2): 271-7. Retrieved from http://www.ncbi.nlm.nih.gov/pubmed/ 3486233

Febbraio MA, Steensberg A, Walsh R, Koukoulas I, van Hall G, Saltin B, Pedersen BK (2002) Reduced glycogen availability is associated with an elevation in HSP72 in contracting human skeletal muscle. J Physiol 538(Pt 3):911-917. Retrieved from http://www.ncbi.nlm. nih.gov/pubmed/11826174

Fehrenbach E, Niess AM, Voelker K, Northoff H, Mooren FC (2005) Exercise intensity and duration affect blood soluble HSP72. Int J Sports Med 26(7):552-557. doi:10.1055/s-2004-830334

Gelain DP, de Bittencourt Pasquali MA, Comin MC, Grunwald MS, Ritter C, Tomasi CD, Alves SC, Quevedo J, Dal-Pizzol F, Moreira JC (2011) Serum heat shock protein 70 levels, oxidant status, and mortality in sepsis. Shock 35(5):466-470. doi:10.1097/SHK. 0b013e31820fe704 
Hightower LE, Guidon PT (1989) Selective release from cultured mammalian cells of heat shock (stress) proteins that resemble glia-axon transfer proteins. J Cell Physiol 138(2):257-266

Hishikawa T, Cheung JY, Yelamarty RV, Knutson DW (1991) Calcium transients during $\mathrm{Fc}$ receptor-mediated and nonspecific phagocytosis by murine peritoneal macrophages. J Cell Biol 115(1):59-66. Retrieved from http://www.ncbi.nlm.nih.gov/pubmed/1918139

Jaattela M (1999) Heat shock proteins as cellular lifeguards. Ann Med 31(4):261-271

Johnson JD, Fleshner M (2006) Releasing signals, secretory pathways, and immune function of endogenous extracellular heat shock protein 72, 79(March):425-434. doi:10.1189/jlb.0905523.Journal

Kindas-Mugge I, Steiner G, Smolen JS (1993) Similar frequency of autoantibodies against $70-\mathrm{kD}$ class heat-shock proteins in healthy subjects and systemic lupus erythematosus patients. Clin Exp Immunol 92(1):46-50. Retrieved from http://www.ncbi.nlm.nih. gov/pubmed/8467563

Lancaster GI, Moller K, Nielsen B, Secher NH, Febbraio MA, Nybo L (2004) Exercise induces the release of heat shock protein 72 from the human brain in vivo. Cell Stress Chaperones 9(3):276-280. Retrieved from http://www.ncbi.nlm.nih.gov/pubmed/15544165

Li Y.-H, Yan Z.-Q, Brauner A, Tullus K (2002) Activation of macrophage nuclear factor-kappa $\mathrm{B}$ and induction of inducible nitric oxide synthase by LPS. Respir Res 3:23. Retrieved from http://www. pubmedcentral.nih.gov/articlerender.fcgi?artid=150509\&tool= pmcentrez\&rendertype $=$ abstract

Lindquist S, Craig EA (1988) The heat-shock proteins. Annu Rev Genet 22:631-677. doi:10.1146/annurev.ge.22.120188.003215

Lombardo E, Alvarez-Barrientos A, Maroto B, Bosca L, Knaus UG (2007) TLR4-mediated survival of macrophages is MyD88 dependent and requires TNF-alpha autocrine signalling. J Immunol 178(6):3731-3739. Retrieved from http://www.ncbi.nlm.nih.gov/ pubmed/17339471

Luong M, Zhang Y, Chamberlain T, Zhou T, Wright JF, Dower K, Hall JP (2012) Stimulation of TLR4 by recombinant HSP70 requires structural integrity of the HSP70 protein itself. J Inflamm (Lond Engl) 9: 11. doi:10.1186/1476-9255-9-11

Matzinger P (2002) The danger model: a renewed sense of self. Science 296(5566):301-305. doi:10.1126/science.1071059

Millar DG, Garza KM, Odermatt B, Elford AR, Ono N, Li Z, Ohashi PS (2003) Hsp70 promotes antigen-presenting cell function and converts T-cell tolerance to autoimmunity in vivo. Nat Med 9(12): 1469-1476. doi:10.1038/nm962

Ortega E, Giraldo E, Hinchado MD, Martinez M, Ibanez S, Cidoncha A, Collazos ME, Garcia JJ (2006) Role of Hsp72 and norepinephrine in the moderate exercise-induced stimulation of neutrophils' microbicide capacity. Eur J Appl Physiol 98(3):250-255. doi:10.1007/ s00421-006-0269-7

Ortega E, Hinchado MD, Martin-Cordero L, Asea A (2009) The effect of stress-inducible extracellular Hsp72 on human neutrophil chemotaxis: a role during acute intense exercise. Stress 12(3):240-249. doi:10.1080/10253890802309853

Peck G, Andrades M, Lorenzi R, da Costa M, Petronilho F, Moreira JCF, ... Ritter C (2009). Serum-induced macrophage activation is related to the severity of septic shock. Inflammation research : official journal of the European Histamine Research Society... [et al.] 58(2):89-93. doi:10.1007/s00011-009-8088-z

Pittet JF, Lee H, Morabito D, Howard MB, Welch WJ, Mackersie RC (2002) Serum levels of Hsp 72 measured early after trauma correlate with survival. J Trauma 52(4):611-617, discussion 617

Pockley AG, Georgiades A, Thulin T, de Faire U, Frostegard J (2003) Serum heat shock protein 70 levels predict the development of atherosclerosis in subjects with established hypertension. Hypertension 42(3):235-238. doi:10.1161/01.HYP.0000086522. 13672.23
Ribeiro SP, Villar J, Downey GP, Edelson JD, Slutsky AS (1994) Sodium arsenite induces heat shock protein-72 kilodalton expression in the lungs and protects rats against sepsis. Crit Care Med 22(6):922-929. Retrieved from http://www.ncbi. nlm.nih.gov/pubmed/7794296

Ritossa F (1962). A new puffing pattern induced by temperature shock and DNP in drosophila. Cell Mol Life Sci 18(12).

Ruan BH, Li X, Winkler AR, Cunningham KM, Kuai J, Greco RM, Nocka KH, Fitz LJ, Wright JF, Pittman DD, Tan XY, Paulsen JE, Lin LL, Winkler DG (2010) Complement C3a, CpG oligos, and DNA/ C3a complex stimulate IFN-alpha production in a receptor for advanced glycation end product-dependent manner. J Immunol 185(7):4213-4222. doi:10.4049/jimmunol.1000863

Ryan AJ, Flanagan SW, Moseley PL, Gisolfi CV (1992) Acute heat stress protects rats against endotoxin shock. J Appl Physiol 73(4):15171522

Skehan P, Storeng R, Scudiero D, Monks A, McMahon J, Vistica D, Warren JT, Bokesch H, Kenney S, Boyd MR (1990) New Colorimetric Cytotoxicity Assay for Anticancer-Drug Screening. JNCI J Natl Cancer Inst 82(13):1107-1112. doi:10.1093/jnci/82. 13.1107

Srivastava P (2002) Interaction of heat shock proteins with peptides and antigen presenting cells: chaperoning of the innate and adaptive immune responses. Annu Rev Immunol 20:395-425. doi:10.1146/ annurev.immunol.20.100301.064801

Trautinger F, Kindas-Mugge I, Knobler RM, Honigsmann H (1996) Stress proteins in the cellular response to ultraviolet radiation. $\mathrm{J}$ Photochem Photobiol B 35(3):141-148. Retrieved from http:// www.ncbi.nlm.nih.gov/pubmed/8933720

Trautinger F, Knobler RM, Honigsmann H, Mayr W, Kindas-Mugge I (1996) Increased expression of the $72-\mathrm{kDa}$ heat shock protein and reduced sunburn cell formation in human skin after local hyperthermia. J Invest Dermatol 107(3):442-443. Retrieved from http://www. ncbi.nlm.nih.gov/pubmed/8751984

Vega VL, Rodriguez-Silva M, Frey T, Gehrmann M, Diaz JC, Steinem C, Multhoff G, Arispe N, De Maio, A (2008) Hsp70 translocates into the plasma membrane after stress and is released into the extracellular environment in a membrane-associated form that activates macrophages. J Immunol 180(6):4299-4307. Retrieved from http://www.ncbi.nlm.nih.gov/pubmed/18322243

Venereau E, Casalgrandi M, Schiraldi M, Antoine DJ, Cattaneo A, De Marchis F, Liu J, Antonelli A, Preti A, Raeli L, Shams SS, Yang H, Varani L, Andersson U, Tracey KJ, Bachi A, Uguccioni M, Bianchi ME (2012) Mutually exclusive redox forms of HMGB1 promote cell recruitment or proinflammatory cytokine release. J Exp Med 209(9):1519-1528. doi:10.1084/jem.20120189

Villar J, Ribeiro SP, Mullen JB, Kuliszewski M, Post M, Slutsky AS (1994) Induction of the heat shock response reduces mortality rate and organ damage in a sepsis-induced acute lung injury model. Crit Care Med 22(6):914-921

Walsh RC, Koukoulas I, Garnham A, Moseley PL, Hargreaves M, Febbraio MA (2001) Exercise increases serum Hsp72 in humans. Cell Stress Chaperones 6(4):386-393. Retrieved from http://www. ncbi.nlm.nih.gov/pubmed/11795476

Wong HR, Menendez IY, Ryan MA, Denenberg AG, Wispe JR (1998) Increased expression of heat shock protein-70 protects A549 cells against hyperoxia. Am J Physiol 275(4 Pt 1):L836-L841

Wong HR, Ryan M, Menendez IY, Denenberg A, Wispe JR (1997) Heat shock protein induction protects human respiratory epithelium against nitric oxide-mediated cytotoxicity. Shock 8(3):213-218

Zanotto-Filho A, Braganhol E, Battastini AM, Moreira JC (2012) Proteasome inhibitor MG132 induces selective apoptosis in glioblastoma cells through inhibition of PI3K/Akt and NFkappaB pathways, mitochondrial dysfunction, and activation of $\mathrm{p} 38-\mathrm{JNK} 1 / 2$ signaling. Investig New Drugs 30:2252-2262 